Covered in: CrossRef; RePEc; CEEOL; KVK; WorldCat; Google Scholar

2020, Volume 4, Issue 2, pages: 01-19 | https://doi.org/10.18662/mjesp/4.2/18

\section{Psychological Strengths \\ Contributing to Rural Student's Academic Performance in Kadazandusun}

Getrude C. AH GANG GRACE ${ }^{1}$

${ }^{1}$ Faculty of Psychology and Education, University Malaysia Sabah, Kota Kinabalu, Malaysia, getrudec@ums.edu.my
Abstract: Achieving academic success is a shared dream among students. To achieve academic success, psychological strengths, such as psychological well-being, academic selfefficacy, and motivation, are predictors of students' academic achievement. To examine these factors, a study was conducted on rural students from the Kadazandusun community residing in the interior Sabah division. It is predicted that each of these psychological factors may contribute to the academic achievement of these rural students. There were 668 Kadazandusun rural students from 17 rural schools in Sabah who participated in this study. A set of questionnaires comprising four parts was used to measure all the variables based on the following sequence: Section A measured demographic variables, Section B measured psychological wellbeing, Section C measured achievement motivation, and Section D measured academic self-efficacy. The simple regression analysis showed that each psychological factor moderately affected academic achievement. Psychological wellbeing, achievement motivation, and academic self-efficacy contributed $4.4 \%, 2.2 \%$, and $5.1 \%$ of the variance in students' academic achievement, respectively. This study's results may give the Ministry of Education, schools, and parents a glimpse of hope that despite educational limitations, such as lack of infrastructure and geographical location, students' psychological strengths can enhance rural students' academic performance. Therefore, the educational authorities can provide more programmes regarding works that increase psychological well-being, motivation, and academic efficacy, which may contribute to the academic success of rural students.

Keywords: psychological well-being, academic self-efficacy, achievement motivation, academic performance.

How to cite: Ah Gang Grace, G. C. (2020). Psychological Strengths Contributing to Rural Student's Academic Performance in Kadazandusun. Moldavian Journal for Education and Social Psychology, 4(2), 01-19. https://doi.org/10.18662/mjesp/4.2/18 


\section{Introduction}

The common goal most students have while on their academic journey is to obtain excellent academic results. Most students strive for excellence in academics despite the challenges they face. For instance, in some parts of rural Sabah, students face impediments, such as a lack of infrastructural development, geographical location, low standard of living, and inadequate educational facilities. These are some of the challenges students face in Sabah interior schools that may affect their academic performance. Regarding geographical conditions, Sabah is vast and contains flatlands, mountainous regions, and small islands, which makes access to education and educational facilities difficult (UNICEF Malaysia, 2019). The geographical conditions in some rural areas of Sabah are difficult to access, while some areas can only be reached using almost inaccessible roads or river transport systems (Marwan et al., 2012). Additionally, rural students in some parts of Sabah and Sarawak have to walk three to six hours to school every day, going through thick forests, suspension bridges, and rivers to access education (Yunus, 2014).

This challenge was solved by equipping rural schools with dormitories that could accommodate students who lived far from their schools (Yunus, 2014). These boarding schools were provided by governmental and non-governmental organisations, such as Petronas (Ridhwan, 2017; Geraldine, 2019), La Salle Brothers (Thien, 2018), and SP Setia Foundation (The Star, 2014). In rural Nabawan, Sabah, for instance, the hostel built by La Salle Brothers provided rural students who came from poor families with the opportunity to stay close to their schools. Most students come from native communities in remote settlements, which are only accessible through boat rides and hours of walking (Thien, 2018). The Petronas also provided dormitories for rural schools in Sabah and Sarawak through the 'Rural Daily Hostel' project (John, 2017). The boarding facilities provided by these organisations relieve students' difficulties in accessing education. Thus, students can spend more time and concentration on their study. Previously, some students commented that going to school was tiring because they had to trek through the hills and sometimes needed to be cautious of wild boars. They also occasionally missed classes because their parents would not allow them to take boats to school during bad weather or lacked enough money to pay for their boat fare (Geraldine, 2019).

Besides geographical conditions, a lack of infrastructure, such as electricity, road networks, and access to technology, posed challenges for students and teachers. During the COVID-19 pandemic, the lack of 
infrastructure in certain rural areas caused great concern among students and teachers, who found it difficult to engage in online classes. These problems have been discussed on social media in hopes that relevant authorities can help solve the problems faced by rural students. Sabah and Sarawak face problems such as bad road networks, poor water and electricity supply, lack of health, education, transport, and digital infrastructure (Yeo, 2020). Regarding access to technology, according to Sabah's Assistant Education Minister, during her recent interview on Astro Awani, $70 \%$ of the students living in rural and remote islands of Sabah lack internet facilities or access to technology, which subsequently impedes online learning classes and students missing out on quality education (Borneo Post Online, 2020). Most of the previous studies (Bjerede, 2018) showed that limited internet access, experienced when obtaining additional knowledge from the internet, is among the challenges faced by rural students. Amid the Covid19 pandemic, rural teachers shared their struggles in reaching out and engaging their students in online classes. This is because some students, especially those living on islands and plantations, not only lack the facilities, such as computers, smartphones, or other mobile devices that can facilitate the delivery process of online learning, but also lack efficient internet access (The Star, 25 April, 2020).

Social media also showed rural students who strongly resolved to access education amid difficulties. For instance, the viral story of Veveonah, a university student who challenged herself to stay on a tree for 24 hours to get good internet connection for an online exam (Lee, 2020); a group of school boys in Sabah who searched for a high spot in the deep jungle to access the internet and hung around on a collapsed bridge (The Borneo Post Online, 2020); and a boy who found a solution by putting a WIFI modem into a plastic bottle and pulled it up to the roof to get good internet connection (Daily Express, 2020). More stories showing rural students using various strategies to access education also appeared on social media platforms during the pandemic. These few examples showed that, despite the struggles and challenges faced by rural students, their psychological strengths helped them overcome those strains to strive for education. All of this may open the eyes of the public and authorities to the initiative taken by these rural students to obtain knowledge. This may also motivate other rural students who have similar problems.

The rural students in the above-mentioned stories who strove to access knowledge might have been influenced by intrinsic psychological factors, such as their psychological well-being, academic self-efficacy, and achievement motivation. Despite facing all of these challenges, students in 
rural areas persistently showed endurance by achieving academic excellence with support from their dedicated teachers and parents. This can be seen in some rural teachers who continued to send homework and learning materials to students under the cooperation of their parents during the COVID-19 pandemic. The efforts of these parties (teachers and parents) might help enhance students' psychological well-being, academic selfefficacy, and achievement motivation in achieving high academic performance. A report from the local news on rural students' great achievements despite facing hurdles showed that nothing can stop rural students from achieving their academic goals. For instance, in the 2018 Malaysia Certificate of Education (SPM), students in rural schools made history by outperforming their peers in urban schools with their SPM results. The rural schools recorded $88.18 \%$ of candidates who passed all subjects, while their urban peers recorded $87.19 \%$, indicating that the quality of education in rural schools in the state has been improving annually (The Sun Daily,2019).

Regarding academic achievement among Kadazandusun students, the Kadazandusun Cultural Association (KDCA) organised the annual Huguan Siou Excellent Education Award in 1997 for students who performed excellently in exam. Besides recognition events, the association also organised the Excellent Students' Motivation Camp since 1999 to help students perform better in their examinations. The KDCA's urged the Kadazandusun community to work together with the association to improve their children's academic achievement (Daily Express, 2004).

This study aims to examine the psychological factors that can enhance the academic achievement of Kadazandusun rural students. It focuses on the Kadazandusun rural students because most of them lived in the interior of Sabah (Puyok, 2020). Also, Kadazandusun students come from the largest ethnic group in Sabah (Asgard, 2002; Augustinea \& Dolinting, 2016). The Kadazandusun is customarily associated with rural development (Puyok, 2020). This may be because they are traditional farmers who mainly grow rice as food crop. They inhabit mainly the western and interior parts of Sabah (Asgard, 2002) and predominantly engage in agricultural activities (Puyok, 2020).

This study focuses on rural areas to understand the impact of psychological factors on students' academic performance. Schools in rural areas play a significant role in helping a nation educate its people (Marwan et al., 2012). The outcome of this study can provide data to education authorities, such as the Ministry of Education, schools, Parent-Teacher Association, and the public on the importance of psychological factors and their impact on rural students' academic achievement. This provides 
essential information needed by relevant authorities to improve the standards of academic performance of rural students.

\section{Literature Review}

A review of previous studies that explored the impact of psychological factors (i.e., psychological well-being, academic self-efficacy, and achievement motivation) on rural students' academic performance showed varying results. For instance, a study conducted by Che Hassan and Thava (2017) involving 100 secondary aboriginal students from Kuala Langat, Selangor, showed a positive correlation between intrinsic and extrinsic motivation on students' academic performance. Aboriginal students who were highly motivated towards education showed a better understanding of the purpose of education, the importance of education, and how to improve themselves and their communities through education. Students who were highly motivated also perceived that the learning process was easier and that the chances of success were high.

Another study by Albert (2004) found that the academic achievement of Kadazandusun Sungai students in the interior Tongod, Sandakan are moderate. In addition, the study found that students' academic performance correlated with their socioeconomic status. In this study, most of the students lived in poverty and lacked education and healthcare. Albert's study does not follow Che Sulaiman et al.'s study (2020), which showed that parents' socioeconomic status does not influence students' academic achievement. Parents' socioeconomic status can only influence students' behaviour and other factors such as mind-set, passion, and selfmotivation to succeed in life.

Ford and Roby (2013) involved 225 high school students aged between 14-18 years with a mean age of 15 years in the Cape Fear Region of North Carolina and found that numerous high school students lacked the desire to perform academic tasks. They often felt detached from their actions and lacked the motivation needed to complete their task. Additionally, many were bored in the classroom because they lacked a sense of belonging or connection. Moreover, they are lacking in academic background knowledge, and they seem to increasingly lag behind annually, which results to additional pressure and the feeling of never 'catching-up'.

Regarding the effects of psychological well-being on academic performance, a systematic review of previous studies by Grabel (2017) showed a positive relationship between psychological well-being and academic achievement. While Cadime et al. (2016) showed that secondary school pupils with higher levels of psychological well-being feel more vitality 
and vigour, are more persistent in adverse situations, maintain effort in their academic work and consequently achieve higher academic achievement. This may be because students with high psychological well-being perceive themselves as progressing in their personal lives and goals; thereby contributing to their self-acceptance and inter-personal relations. All of these factors may lead to higher academic performance.

Besides psychological well-being, another psychological strength that also contributes to rural students' academic performance is academic selfefficacy. A study conducted by Basith et al. (2020) showed that self-efficacy has a positive relationship and is also a predictor in determining academic achievement. Any improvement in academic self-efficacy will be accompanied by an improvement in the academic achievement. The findings were supported by Gang et al.'s (2019) study, which showed that academic self-efficacy is one of the factors contributing to rural students' academic performance. This showed that when students realise their capabilities, they have the confidence and put efforts to reach their goal. Moreover, when students believe that they cannot achieve their goals, their behaviour, actions, and attitudes will indirectly lead them in that direction.

The above-mentioned studies showed that the three psychological strengths-psychological well-being, motivation, and self-efficacycontributed to students' academic performance.

\section{Methodology}

\section{Study Design}

This study design is based on a survey method in which students were given a set of questionnaires with four sections measuring students' demographic profile (e.g., age, gender, academic year, and academic achievement), psychological well-being, achievement motivation, and academic self-efficacy. The study began once ethics approval was obtained from the Ministry of Education to conduct this study in rural schools in Sabah. A meeting was arranged with prospective school principals and teachers, who assisted in delivering the questionnaires to students before proceeding to data collection. The schools' list was obtained from the Sabah Department of Education, Ministry of Education.

\section{Participants}

There were 668 participants from 17 secondary schools in rural Sabah who participated in this study. Their ages ranged from 15-17 years, with a mean age of $15.37(\mathrm{SD}=.52)$. Among the participants, 385 were 
female (56.60\%), 282 were male (42.20\%), and one participant did not reveal gender.

\section{Instruments}

There were four sections in the questionnaire survey. The sections are as follows:

\section{Section A: Demographics (age, location, sex)}

This section comprises 18 items measuring the participants' demographic profiles-age, gender, ethnicity, level of education and academic performance.

\section{Section B: Achievement Motivation Inventory}

This scale comprises 19 items adapted from Muthee and Thomas' scale (2009). The response scale is based on a 5-point Likert scale ranging from 1 'completely disagree' to 5 'completely agree'. The sample items included 'I plan ahead what subjects to study during my free time', 'I always work very hard to be among the best students in my school', and 'Sometimes, I forget to do my homework'. The higher the score, the higher the students' motivational level.

\section{Section C: Academic Self-Efficacy}

The academic self-efficacy scale was developed by Hoover-Dempsey and Sandler (2005). The scale comprises three items measuring students' academic efficacy: ability to complete work successfully, trying to do even the hardest homework and figuring out difficult homework. Each student will rate these items based on a four-point Likert scale from 1 'not true to 4 'very true'.

\section{Section C: Ryff's Psychological Well-Being Inventory}

The psychological well-being was measured using the Ryffs Psychological Well-Being Inventory (Ryff,1989), comprising 42 items. The scale consists of 20 negative items, and these items were reverse-scored so that higher scores corresponded to greater psychological well-being. The response scale provided was 1 (strongly disagree) to 6 (strongly agree). In this scale, participants who scored higher on psychological well-being have a positive view of themselves (self-acceptance), gain independence, and selfdetermination regarding their beliefs and behaviour (autonomy) and have close relationships with others based on mutual trust (positive interpersonal relationships). All of these elements were measured in this scale. 


\section{Data Screening and Cleaning}

Before the data were analysed, several factors, such as the normality of the data and missing values, were considered. Possible outliers for each scale were checked using standardised scores or z-scores. Standardised scores in excess of $3.29(\mathrm{p}<.001$, two-tailed test) were identified as potential outliers (Tabachnick \& Fidell, 2001). The extremeness of a standardised score in excess of 3.29 is expected (Tabachnick \& Fidell, 2001, p.67). In this study, the total number of participants before screening was 670, which reduced to 668 after screening. The skewness and kurtosis for the five scales were considered acceptable (i.e., below 2).

Table 1

The Values of Skewness and Kurtosis for Each Scale

\begin{tabular}{lll}
\hline Scales & Skewness & Kurtosis \\
\hline Psychological well-being & .39 & .89 \\
Achievement motivation & -.22 & -.07 \\
Academic self-efficacy & .50 & 1.38 \\
\hline
\end{tabular}

The values for asymmetry and kurtosis between -2 and +2 were considered acceptable to prove normal univariate distribution (George \& Mallery, 2010). West et al. (1995) proposed a reference of substantial departure from normality as an absolute skew value $>2$. Kurtosis is a measure of sharpness of the peak of a distribution. The original kurtosis value is sometimes called kurtosis, and West et al. (1995) proposed a reference of substantial departure from normality as an absolute kurtosis (proper) value $>7$. The missing values for psychological well-being is $4.34 \%$, achievement motivation is $0.44 \%$ and academic performance is $2.84 \%$. The remaining variables did not have missing values.

\section{Data Analysis}

The data were analysed using SPSS (Statistical Package for Social Sciences) and descriptive and inference analysis. The hypotheses were analysed using hierarchical regression. 
Table 2

Reliability V alues of Each Scale $(N=668)$

\begin{tabular}{lll}
\hline Scales & $\begin{array}{l}\text { Number } \\
\text { items }\end{array}$ & of \\
\hline Achievement motivation & 19 items & .83 \\
Academic self-efficacy & 3 items & .64 \\
Psychological well-being & 42 items & .77 \\
\hline
\end{tabular}

\section{Results}

Among the participants, 385 were female (56.60\%), 282 were male $(42.20 \%)$, and one participant did not reveal the gender. Only $323(48.40 \%)$ participants engaged in outdoor programmes, $326(48.80 \%)$ were never involved, and $19(2.80 \%)$ were missing values. Participants' ages were between 15-17 years. The mean age was $15.36(\mathrm{SD}=.52)$.

Table 3

Demographic Profiles of Participants $(N=668)$

\begin{tabular}{lcc}
\hline Variables & Number & Percentage \\
\hline Gender & & \\
Male & 282 & 42.20 \\
Female & 385 & 56.60 \\
Missing & 1 & .10 \\
\hline Districts & & \\
Beaufort & 67 & 10.00 \\
Keningau & 179 & 26.80 \\
Kuala Penyu & 75 & 11.20 \\
Membakut & 39 & 5.80 \\
Pensiangan & 8 & 1.20 \\
Sipitang & 12 & 1.80 \\
Tambunan & 248 & 37.10 \\
\hline
\end{tabular}


Motivational Aspect and Readiness of Teacher Assistant to Professional Activity Bohdana TURKO, Lyubov NOS

\begin{tabular}{|c|c|c|}
\hline Tenom & 40 & 6.0 \\
\hline $\begin{array}{l}\text { Academic Achievement } \\
\text { Failed all subjects } \\
\text { Pass but unsatisfactory (mostly } \\
\text { grade D) } \\
\text { Pass (with grades C and D) } \\
\text { Pass and satisfactory (A and B) } \\
\text { Excellence } \\
\text { Missing }\end{array}$ & $\begin{array}{r}30 \\
422 \\
109 \\
81 \\
7 \\
19\end{array}$ & $\begin{array}{c}4.5 \\
63.20 \\
16.30 \\
12.10 \\
1.0 \\
2.80\end{array}$ \\
\hline $\begin{array}{l}\text { Involvement in outdoor } \\
\text { programmes (outside schools) } \\
\text { Yes } \\
\text { No } \\
\text { Missing }\end{array}$ & $\begin{array}{r}323 \\
326 \\
19 \\
\end{array}$ & $\begin{array}{r}48.40 \\
48.80 \\
2.80 \\
\end{array}$ \\
\hline $\begin{array}{l}\text { Father's occupation } \\
\text { Not working } \\
\text { Working with governmental sectors } \\
\text { Self-employed }\end{array}$ & $\begin{array}{l}206 \\
190 \\
272\end{array}$ & $\begin{array}{l}30.80 \\
28.40 \\
40.70\end{array}$ \\
\hline $\begin{array}{l}\text { Mother's occupation } \\
\text { Not working } \\
\text { Working with governmental sectors } \\
\text { Self-employed }\end{array}$ & $\begin{array}{r}433 \\
77 \\
158 \\
\end{array}$ & $\begin{array}{l}64.80 \\
11.50 \\
23.70 \\
\end{array}$ \\
\hline $\begin{array}{l}\text { Siblings } \\
1-5 \\
6-10 \\
11-15 \\
16-20 \\
\text { Missing values }\end{array}$ & $\begin{array}{r}369 \\
240 \\
25 \\
1 \\
33\end{array}$ & $\begin{array}{r}55.20 \\
35.90 \\
3.70 \\
0.10 \\
4.90\end{array}$ \\
\hline
\end{tabular}

The simple regression analyses were used to analyse the data. The results showed that each factor contributed a moderate effect on academic achievement. 
Table 4

Simple Regression Analyses with Psychological Well-being, Acbievement Motivation, and Academic Self-Efficacy on Academic Performance

Predictors Academic achievement

\begin{tabular}{llll}
\hline & $\mathrm{R}^{2}$ & $\beta$ & Sig \\
\hline Psychological well-being & .044 & .21 & .00 \\
\hline Achievement Motivation & .022 & .15 & .00 \\
\hline Academic self-efficacy & & & \\
\hline
\end{tabular}

Psychological well-being contributed $4.4 \%$ on the variance of students' academic achievement. This means that the higher the psychological well-being, the higher the students' academic achievement. Achievement motivation contributed $2.2 \%$ of students' academic achievement, and academic self-efficacy contributed $5.1 \%$ of the variance of academic achievement.

\section{Limits and Discussion}

This study only involved Kadazandusun students from the Sabah interior division and did not cover the other four Sabah divisions: Tawau, Sandakan, Kudat, and West coast. Therefore, the study outcome can only represent Kadazandusun students from one specific division. Despite this limitation, this study can contribute to discovering the importance of psychological factors in enhancing rural students' academic performance. Another limitation is that the study did not measure other significant psychological factors that may have also contributed to students' academic achievement, such as assistance and support from teachers and parents. Future studies should consider these factors.

In this study, we found that each psychological factor (i.e., achievement motivation, psychological well-being, and academic selfefficacy) contributed to students' academic performance. Achievement motivation showed a significant and positive effect on academic achievement. This finding supported our prediction and previous studies 
(e.g., Ekpenyong et al., 2017; Kusurkar et al.,2013; Syed Mustafa et al., 2010) that achievement motivation may increase students' academic performance. Achievement motivation is an essential element that contributes to academic performance. In this study, achievement motivation referred to hard work, never leaving a task or assignment, spending more time on schoolwork and never wasting time. The operational definition of achievement motivation shows that concentration and perseverance in academic tasks may enhance students' academic achievement. Besides, it is assumed that achievement motivation may provide students with life purpose and academic goals, as emphasised by Dislen (2013) that motivation provides students with a purpose and direction.

Students' achievement motivation may also be obtained from those close to them, such as parents, teachers, and friends. Regarding rural students, some may have to deal with different expectations from their parents. Parents may expect their children to continue their studies to obtain relevant jobs for a better life. This is because they do not want their children to continue living in poverty and without jobs. Corbet and Woodrum (In Howley et al., 2009) stated that parents of rural students expect that their children will further their study and will leave the community to obtain appropriate employment. Therefore, their life's purpose to gain good knowledge might also come from their parents, who wish for a brighter future for their children. Nonetheless, there are parents who might expect their children only to receive basic knowledge and remain in the community to assist them in farming and other related work.

In some rural communities, parents are suspicious of efforts to locate and provide special services for these students. Sometimes their suspicion reflects the fear that their children will be encouraged to leave the community; their suspicion results from cultural values that focus on collective rather than individual accomplishments (Howley et al., 2009). For instance, some parents may feel that the school system forces children to abstain from activities such as harvesting, which work to reinforce group solidarity and are associated with many cultural traditions (Asgard, 2004). However, nowadays most Kadazandusun parents support their children in pursuing their studies to higher levels, such as college or university. For instance, a father built a temporary hut in a rural village where the children could connect to the internet for online learning during the pandemic (Kedung, 2021). The continuous and positive expectations from parents may instil achievement motivation in rural students.

In this study, psychological well-being also showed a positive contribution to Kadazandusun rural students' academic achievement. Also, 
it defines a student who has a clear sense of direction and purpose, a student with a positive attitude and self-confident. In addition, the student can fit well with people in the community by having few close friends with whom $\mathrm{s} /$ he can share his/her concerns, plan for the future, and make them a reality.

This study's outcome and previous studies (e.g., Cadime et al., 2016; Grabel, 2017) showed that there is a positive relationship between psychological well-being and academic achievement. Cadime et al. (2016) showed that secondary school students with high psychological well-being tend to perceive themselves as progressing in their personal lives, and this contributes to their self-acceptance and interpersonal relationships, which may help increase their psychological well-being. This finding corresponds to a study conducted by Hassanzadeh and Mahdinejad (2013), which showed that motivation can inspire people to progress, and progression contributes to happiness, especially when working towards things that make one happy. Positive school environment, the school culture, and the rapport relationships between students, teachers, and peers play an influential role in their happiness (Jones, 2015).

Also, the harmonious relationships among rural communities is another factor that may contribute to students' psychological well-being. This is usually present in the Kadazandusun community, where, according to Augustinea and Dolinting (2016), the Kadazandusun societies are defined by close kinship, with the family being the most important unit, followed by the village. Solidarity and other positive 'human values' are connected with the 'traditional' way of living among Kadazandusuns (Asgard, 2004). Many studies point to the educational system (students, teachers, parents, school principals, and support staff) as being the most influential in making schools hostile or non-hostile environments (Badri et al., 2018). All the abovementioned factors explain the reasons for the effects of students' psychological well-being on their academic achievement. Through education, students can also influence other aspects of their lives, such as their psychological well-being.

Academic self-efficacy also contributes to students' academic performance. This study and previous studies, such as Van der Westhuizen et al.'s (2014) study, showed that students' beliefs about their own potential and abilities regarding research could relatively influence their success. It is recommended that research self-efficacy and other psychological strengths as predictors of academic success be further investigated. Bandura (2002) defined self-efficacy as the belief in accomplishing whatever one wants to accomplish. Perceived self-efficacy is defined as one's evaluation or 
judgement of one's capabilities to organise and execute the courses of action required to attain certain designated types of performances (Bandura, 2002). In this study, academic self-efficacy is defined as the ability to figure out, perform, and accomplish academic work successfully.

When students feel better about their academic abilities, more ambitious challenges, better known as self-efficacy, are perceived. However, when self-efficacy is doubted, failure can be expected as an obvious result. It has been predicted that students who are detached or disconnected from school have little belief in their academic ability. Belief in one's ability and effort are equally necessary antecedents of successful academic student achievement. Self-confidence is a vital element, as students have to believe that they have what it takes to effectively perform in the classroom. It is a widespread belief that most students lack the ability and do not trust that they can maintain the effort required to complete their academic studies successfully. Numerous high school students find themselves lacking the desire to do academic tasks. They often feel detached from their actions, causing them to lack the motivation needed to complete their tasks (Ford \& Roby, 2013).

\section{Conclusions}

This study showed that each psychological strength may help to elevate students' academic achievement. This study provides better information on the impact of rural students' psychological strengths in gaining excellent academic achievement to relevant authorities. The study suggested that the Ministry of Education and other educational organisations should consider the impact of psychological strengths on students' academic achievement, also to providing the development. The authority should note that excluding providing tangible assistance in the form of infrastructure, they should also provide intervention programmes with a focus on increasing students' motivation, academic self-efficacy, and psychological well-being levels because these may help to improve rural students' academic achievement. Future studies may consider exploring other psychological strengths that can help increase students' academic performance, such as their life difficulties, resilience, and community's support derived from their parents, teachers, and peers.

\section{Acknowledgement}

My appreciation goes to the Ministry of Education for the ethics approval to conduct this study and to the school principals and teachers in the selected 
rural schools who supported during the data collection process. Also, I highly appreciate to all the students who participated in this study for their kind support and generous assistance.

\section{References}

Augustinea,E.C., \& Dolinting, T.J.(2016).Sustainable Social Services: Human and Nature in Harmony, Procedia - Social and Behavioral Sciences,224,579 - 586

Albert, B.(2004) Status Ekonomi Keluarga Dan Hubungkaitnya Dengan Prestasi Akademik Pelajar-pelajar Kadazan Dusun Di Daerah Tongod, Telupid, Sandakan Sabah. Masters thesis, Universiti Teknologi Malaysia.

Asgard, B.(2002).Ethnic awareness development: A study of the Kadazandusun, Sabah, Malaysia,https://ohlininstitutet.se/wpcontent/uploads/2008/09/mfs_malaysia.pdf

Badri, M., Al Nuaimi, A., Guang, Al Sheryani, Y., \& Al Rashedi, A.(2018). The effects of home and school on children's happiness: a structural equation model. ICEP,12, 17 https://doi.org/10.1186/s40723-018-0056-z

Basith, A., Syahputra,A., \& Ichwanto, M.A.(2020).Academic Self-Efficacy As Predictor of Academic Achievement,Jurnal Pendidikan Indonesia,9(1),163170.doi:10.23887/jpj-undiksha.v9i7.24403

Bjerede, M.(2018).Rural districts face challenges and opportunities with technology access, EdTech Magazine,https://edtechmagazine.com/k12/article/2018/01/ruraldistricts-face-challenges-and-opportunities-technology-access

Borneo Post Online.(12 September, 2013).Sabah rural residents first to use new and fast Internet,http://www.theborneopost.com/2013/09/18/sabah-ruralresidents-first-to-use-new-and-fast-internet/

Cadime, Irene., Pinto,A.M, Lima,S.,Rego, S., Pereira,J., \& Ribeiro,I.(2016).Wellbeing and academic achievement in secondary school pupils: The unique effects of burnout and engagement, Journal of Adolescence, 53,169-179

Che Sulaiman, N.F., Mohammad Akhir, N.H.,Hussain,N.E., Md Jamin, R., \& Ramli, N.H.(2020). Data on the impact of socioeconomic status on academic achievement among students in Malaysian public universities,Data in Brief,31,1-8 https://reader.elsevier.com/reader/sd/pii/S2352340920309124?token $=43$ E2DF3CB872E2AEC163DF634A451C51D9E6F89C4B3449CFA5DEA9 83CA0138C62F89D6DF9586797359E86E02E5A1F41A

Che Hassan, N., \& Thava, M.(2017). Motivation and Academic Achievement: A Case Study of Malaysian Aboriginal (Orang Asli) Students, International Journal of Academic Research in Business and Social Sciences, 7, 534-549,Special Issue - 4th International Conference on Educational Research and Practice 
Motivational Aspect and Readiness of Teacher Assistant to Professional Activity Bohdana TURKO, Lyubov NOS

Daily Express.(29 June, 2020).Digital divide: Rural students struggle with online learning, http://dailyexpress.com.my/news/154979/digital-divide-rural-studentsstruggle-with-online-learning/

Daily Express.(December 23, 2004).KDCA's role in success, http://www.dailyexpress.com.my/news.cfm?NewsID $=31548$

Dislen, G.(2013). The reasons of lack of motivation from the students' and teachers' vioces, The Journal of Academic Social Science,1,35-45

Ekpenyong, E.E., Donald, E., \& Joseph, G.(2017). Achievement motivation towards social studies on students' academic achievement in tertiary institutions in cross river state, Nigeria, International Journal of Education, Learning and Development,5,(5), 45-50

Ford, V.B., \& Roby, D.E.(2013).Why do higher school students lack motivation

in the classroom.Global Education Journal,2,101-113 .

Gang, G. C. A., Han, C. G. K., \& Bansa, L. A. (2019). The Contribution of Psychological Factors on Academic Achievement of Rural Students in the Interior School of Sabah Division.International Journal of Education, Psychology and Counseling, 2(27), 76-90.

George, D. \& Mallery, M. (2010).SPSS for Windows Step by Step: A Simple Guide and Reference, 17.0 update (10a ed.) Boston: Pearson.

Geraldine, A.(July 6,2019).Petronas builds 120-bed hostel to boost attendance at Sabah rural school, https://www.nst.com.my/news/nation/2019/07/502026/petronasbuilds-120-bed-hostel-boost-attendance-sabah-rural-school

Grabel,B.F.(2017).The relationship between wellbeing and academic achievement: A systematic review, Master thesis, bttps:// essay.utwente.nl/73514/1/Gr\%C3\%A4bel MA\%20Positive\%20Psycholog y\%20 And\%20Technology Faculty \%200f\%20Behavioral\%2C\%20Managment $\% 20$ $\% 26 \% 20$ Social\%20Science.pdf

Hassanzadeh, R., \&Mahdinejad, G.(2013).Relationship between Happiness and Achievement Motivation: A Case of University Students, Journal of Elementary Education, 23,(1),53-65

Hoover-Dempsey, K.V., \& Sandler, H.M. (2005). Final Performance Report for OERI Grant \# R305T010673: The Social Context of Parental Involvement: A Path to Enhanced Achievement. Presented to Project Monitor, Institute of Education Sciences, U.S. Department of Education, March 22, 2005. (17) (PDF) Contribution of Psychological Factors on Academic Achievement of Rural Students in The Interior School of Sabah Division. Available from:

https://www.researchgate.net/publication/332144163_Contribution_of_P sychological_Factors_on_Academic_Achievement_of_Rural_Students_in_ The_Interior_School_of_Sabah_Division. 
Howley, A., Rhodes, M., \& Beall, R.(2009). Challenges Facing Rural Schools: Implications for Gifted Students Aimee Howley, Megan Rhodes, and Jimmie Beall.Journal for the Education of the Gifted,32(4),515-536.

John,B.(19 October, 2017).Dorms give hope to rural pupils, https://www.nst.com.my/news/nation/2017/10/292545/dorms-givehope-rural-pupils

Jones, V.(March 26, 2015). Because I'm happy: An intriguing study notes a correlation between a student's level of happiness and GPA, https://www.gse.harvard.edu/news/uk/15/03/because-i $\% \mathrm{E} 2 \% 80 \% 99 \mathrm{~m}$ happy

Kedung, BK.(January 22, 2021).Demi capaian internet, ayah bina pondok sementara untuk. anak-anak. [For the sake of internet access, the father built a temporary but for the children],https://www.iloveborneo.my/cerita-menarik-dari-borneo/demicapaian-internet-ayah-ini-bina-pondok-sementara-untuk-anak-anak/

Kusurkar, R.A., Cate, J.T., Vos, M.P., Westers, \& Croiset, G.(2013)._How motivation affects academic performance: a structural equation modelling analysis, Advance Health Science Education Theory Practice,8(1), 5769. doi: $\underline{10.1007 / s 10459-012-9354-3}$

Lee, S.(16 Jun, 2020).Sabah students stays overnight in tree to get better internet connection for online university exams, https://www.thestar.com.my/news/nation/2020/06/16/sabah-unistudent-stays-overnight-in-tree-to-get-better-internet-connection-foronline-exams

Malhoit, G. C. (2005). Providing Rural Students with a High Quality Education: The Rural Perspective on the Concept of Educational Adequacy. Arlington: The Rural School and 186 Educational Issues, Research and Policies Community Trust.

Marie, M., \& Sakac, M.(2014).Individual and social factors related to students' academic achievement and motivation for learning, Suvremena Psihologia, 12(1),63-79

Marwan, A, Sumintono, B \& Mislan, N.(2012).Revitalizing Rural Schools: A Challenge for Malaysia', Educational Issues, Research and Policies, 172-188.

Muniandy, S.(2017).Organisational Citizenship Behaviour (OCB) among Teachers: The Difference between Individual (OCB-I) and Organisational (OCB-O) Level Citizenship Behaviour in Rural and Urban Primary Schools in Sabah, Malaysia, The International Journal Of Business \& Management,4,12, 274-293

Muthee J.M. \& Thomas, I.(2009). Achievement Motivation Inventory,Department of Psychology, University of Kerala

Puyok, A,(2004).Kadazandusun progress: What needs to be done?, Malaysia Kini, https://www.malaysiakini.com/letters/31862

Ridhwan,M.(October 26, 2017).Petronas bantu pembangunan infrastruktur Sabah, bina MRSM dan asrama, https:/ /www.astroawani.com/berita- 
Motivational Aspect and Readiness of Teacher Assistant to Professional Activity Bohdana TURKO, Lyubov NOS

malaysia/petronas-bantu-pembangunan-infrastruktur-sabah-bina-mrsmdan-asrama-158963

Ryff, D.C.(1989).Happiness is everything, or is it?Journal of Personality and Social Psychology,57 (6),1069-1081

Syed Mustafaa,S.M.,Elias, H.,Noah,S.B., \&Roslan, S.(2010). A Proposed Model of Motivational Influences on Academic Achievement with Flow as the Mediator, Procedia Social and Behavioral Sciences, 7,29.doi:10.1016/j.sbspro.2010.10.001

Tabachnick, B.G., \& Fidell,L.S.(2001).Using Multivariate Statistics.(4th Edition). Allyn and Bacon

The Star.(16 July,2014).Foundation builds hostel for Sabah school's students, https://www.thestar.com.my/news/nation/2014/07/16/foundationbuilds-hostel-for-sabah-schools-students,

The Borneo Post Online.(May 20, 2020). Crucial to prioritise internet coverage for all rural schools - Jo-Anna https://www.theborneopost.com/2020/05/20/crucialto-prioritise-internet-coverage-for-all-rural-schools-jo-anna/

The Star.(25 April 2020). Teachers face big challenge in Sabah's rural areas to carry out online learning,

https://www.thestar.com.my/news/nation/2020/04/25/teachersface-big-challenge-in-sabah039s-rural-areas-to-carry-out-onlinelearning

The Sun Daily.(14 March,2019). SPM 2018: Rural students outperform urban peers in Sabah, https://www.thesundaily.my/local/spm-2018-rural-studentsoutperform-urban-peers-in-sabah-AI684200

Thien, S.(26 June 2018). Home away from home for poor students, The Star

https://www.thestar.com.my/metro/metro-news/2018/06/26/home-awayfrom-home-for-poor-students-hostel-run-by-la-salle-brothers-giveschildren-from-the-outski

UNICEF Malaysia.(2019).Children out of school, Malaysia:The Sabah context, https://www.unicef.org/malaysia/media/921/file/Out $\% 20$ of $\% 20$ School $\% 20$ children $\% 20 \% 20$ (OOSCI) $\% 20$ Accessible $\% 20$ version.pdf

Van der Westhuizen, S., De Beer, M., \& Bekwa, N.(2011).Psychological strengths as predictors of postgraduate students' academic achievement, Journal of Psychology in Africa, 21,3, 473-478.

West, S.G, Finch, J.F., \& Curran, P.J. (1995). Structural equation models with nonnormal variables: problems and remedies. In: R.H., Hoyle (Ed.). Structural equation modeling: Concepts, issues and applications. Newbery Park, CA: Sage; pp. 56-75.

World Bank. (2010). Malaysia Economic Monitor, Inclusive 188 Educational Issues, Research and Policies Growth. World Bank: Bangkok, Thailand. Availabel 
at:

http://siteresources.worldbank.org/INTMALAYSIA/Resources/3243921288897994959/mem_nov2010_fullreport.pdf [21 Aug 2011]

Yanbarough, A.(2016). Engaging rural students at the University of Montana through digital stories: Supports and barriers to higher education, A Dissertation, The University of Alabama

Yeo, A.(13 October, 2021).Let no state be left behind,The Sun Daily, https://www.thesundaily.my/opinion/let-no-state-be-left-behindCE4574260

Yunus, A.(July 8,2014).Cabaran pelajar Sabah, Sarawak jadi tumpuan Kementerian Pendidikan [The challenges of Sabah, Sarawak students are the focus of the Ministry of Education],Astro Awani,https://www.astroawani.com/beritamalaysia/cabaran-pelajar-sabah-sarawak-jadi-tumpuan-kementerianpendidikan-39337 